About Our Cover

\section{The "Explorer" Series of Roses from Ottawa and L'Assomption}

Since its origin, the rose has been considered the queen of flowers and is prized for its delicate nature, beauty, charm, and aroma. These plants produce an exquisite floral display consisting of many vibrant colors and perfumes. The first recorded history of the cultivated rose is from the gardens of the Middle East, Greece, and Rome, where the first rosarians initially made selections among local wild species and then from uncontrolled mating between garden-grown roses (Krussmann, 1981). This work produced roses with a wide variety of shapes, forms, and fragrances. These selections were later crossed with the subtropical roses imported to Europe from China during the 18th century (Krussmann, 1981). Further plant improvement was made in the 19th and 20th centuries, giving rise to the modern hybrid tea and floribunda roses that now are grown in many parts of the world. However, one shortcoming of these modem roses is their lack of tolerance to low tempera tures. This attribute is inherited from the Chinese roses and restricts their cultivation to only the mildest areas of the northern United States and Canada. Most of Canada and parts of the northern United States experience extreme winter cold, which can reach at least $-30 \mathrm{C}$.

Because popular hybrid tea and floribunda roses could not be grown successfully without extensive winter protection, Agriculture Canada embarked on a breeding program to introduce desirable hardiness and disease resistance from older roses and floral characteristics of the modem types into roses adapted to continental winter climates. This program was initiated at the Central Experimental Farm in Ottawa, Ontario, Canada, during the early 1960s under the direction of Felicitas Svejda and was transferred to the Experimental Farm at L'Assomption, Quebec, Canada, in 1987. The roses developed from this program are known as the Explorer series, named after notedexplorers of Canada (Ogilvie and Arnold, 1992).

The primary objective of this project was to select bush and climbing roses that would survive northern conditions without artificial winter protection. Initially, Svejda concentrated on selecting improved types of shrub

Received for publication 14 Mar. 1994. Accepted forpublication 19 Dec. 1994. The cost of publishing this paper was defrayed in pan by the payment of page charges. Under postal regulations. this paper therefore must be hereby marked advertisement solely to indicate this fact.

'George Vancouver' rose, one of the latest releases of the Explorer series of winter-hardy roses developed by Agriculture Canada. roses from the hardy diploid $(2 \mathrm{n}=14)$ species Rosa rugosa Thunberg (originating in Siberia and northern Japan) that possessed many petals and a long blooming season (Svejda, 1978b). Germplasm with superior cold resistance and flowering performance at Ottawa were chosen as parents. Crosses were made between the European cultivars Schneezwerg, Frau Dagmar Hastrup, and Souvenir de Philemon Cachet. The release of 'Martin Frobisher', a light-pink rose with few thorns (Svejda, 1969) marked the first cultivar with improved flowers and bloom period to initiate the Explorer series. This release was followed by the mediumpink-flowering 'Jens Munk' (Svejda, 1975); 'Henry Hudson'. a low shrub with appleblossom-pink/white blooms (Svejda, 1977); themedium-red-flowering 'David Thompson' (Svejda, 1979); and the violet-red-blooming 'Charles Albanel' (Svejda, 1982).

Subsequent research concentrated on the introgression of tetraploid $(2 \mathrm{n}=28)$ species cross-compatible with cultivated roses. The more recently registered rose cultivars have originated from crosses of the hardy tetraploid climber $R$. kordesii Wulff. with tetraploid breeding lines developed in western Canada by amateur or commercial breeders, such as Frank Skinner from Manitoba, Percy Wright from Saskatchewan, and George Bugnet and George Simonet from Alberta. The lines they used originated from several cold-tolerant tetraploid wild species (mainly $R$. spinosissima L. and $R$. laxa Retzius) crossed with commercial tetraploid cultivars. Modern floribunda and hybrid tea roses also were used in breeding some of the Explorer roses to obtain flowers with improved appearance and increased numbers of petals.

Subsequent releases combined the hardiness and tolerance to major diseases of the wild species with the long blooming period and attractive flower type of the more tender garden roses. These included climbing and bush types (Svejda, 1981). The climbing types are the first repeat-flowering climbers hardy ( $-35 \mathrm{C}$ or lower) enough to be left on their supports during winter in many parts of Canada. These types generally require only a light pruning of dead wood in the spring. The medium-red-flowering 'John Cabot' was the first of these hardy new climbing types to be registered (Svejda, 1978a). The next release was 'William Baffin', a vigorous plant with large clusters of light-red blossoms (Svejda, 1983). This cultivar is probably the hardiest repeatflowering climbing rose to be released to date. Next in succession was 'Henry Kelsey'. which possesses deep-red flat flowers with many stamens (Svejda, 1985). Subsequent releases include 'John Davis', a hardy rose with beautiful medium-pink flowers closely resembling some of the old classic roses (Svejda, 1988);
'Captain Samuel Holland', possessing a unique shade of fuchsia-red blooms (Ogilvie et al.. 1991); and the extremely floriferous 'Louis Jolliet', which produces large clusters of very double medium-pink flowers (Ogilvie et al., 1992).

The released bush types include 'John Franklin', which possesses medium-red, floribunda-type blossoms (Svejda, 1980). and 'Champlain', which retains an abundance of velvety red, floribunda-type flowers and was probably the most floriferous hardy rose available at the time of its release (Svejda, 1982). 'Alexander Mackenzie', a medium-red grandiflora type (Svejda, 1986), and 'J.P. Connell', the first repeat-flowering, hardy. yellow rose with pale lemon-colored blooms resembling those of a hybrid tea (Svejda, 1988). were also released during this period. Two more recent releases, 'Frontenac', producing large clusters of medium-pink flowers (Ogilvie et al., 1993a), and 'Simon Fraser', with its light-pink, floribunda-type blossoms in largeclusters (Ogilvie and Arnold, 1993) set a new standard of combined hardiness and abundant flower production.

Roses grown in regions experiencing severe winters may be killed to ground level when critically low temperatures $(-20$ to $-30 \mathrm{C}$ ) occur before there is sufficient snow cover $(20$ to $30 \mathrm{~cm})$ to provide a degree of natural insulation. Although grafted or budded roses (the majority of hybrid teas and floribundas) often are killed to the graft point during extremely cold periods, the rootstock will survive. Roses that are grown on their own roots generally will survive such conditions and produce sufficient regrowth to flower in the subsequent growing season. All released lines of the Explorer series have been selected for their ability to perform well on their own roots and for ease of propagation as rooted cuttings. These roses also lend themselves well to multiplication by tissue culture (Arnold et al., 1994). At L'Assomption, Quebec, research involving in vitro methods has provided specific media for the optimum growth of Explorer series releases.

Explorer series roses are all repeat bloomers. and many begin flowering in early spring and persist until frost (Ogilvie et al., 1993b). For instance, 'Simon Fraser' (Ogilvie and Arnold. 1993) has one of the longest flowering periods (5 months at L' Assomption, Quebec) of any hardy rose. Initial blooms may be single. but subsequent blooms contain up to 22 petals.

Two additional cultivars, 'George Vancouver', an erect shrub with medium-red flowers (25-30 petals) and attractive red fruit, and 'Quadra', a climber with dark-red flowers ( $>50$ petals) and attractive red-tinged foliage, were released in 1994 and chosen as the official roses for the Commonwealth Games held in Victoria, British Columbia, Canada.

All Explorer and other roses developed by Agriculture Canada have been registered with the Canadian Ornamental Plant Foundation, 652 Aberdeen Ave., North Bay, Ontario P1B 
(continued from inside front cover)

7H9. They are available in the United States from Bailey Nurseries, 1325 Bailey Rd., St. Paul, MN 55119.

\section{Literature Cited}

Arnold, N.P., M.R. Binns, N.N. Barthakur, and D.C. Cloutier. 1994. A study of the effect of growth regulators and time of plantlet harvest on the in vitro multiplication rate of hardy and hybrid tea roses. J. Hort. Sci. 67:721-135.

Krussmann, G. 1981. The complete book of roses. Timber Press, Portland, Ore.

Ogilvie, I.S. and N.P. Arnold. 1992. Roses from the North. Horticulture 70:26-32.

Ogilvie, I.S. and N.P. Arnold. 1993. 'Simon Fraser' rose. HortScience 28:680.

Ogilvie, I.S.. N.P. Arnold, and D.C. Cloutier. 1991. 'Captain Samuel Holland' rose. HortScience 26:1344-1345.
Ogilvie, I.S., N.P. Arnold, and D.C. Cloutier. 1992. 'Louis Jolliet' rose. HortScience 27:278.

Ogilvie, I.S., N.P. Arnold, and D. Cloutier. 1993a. 'Frontenac' rose. HortScience 28:161.

Ogilvie, I.S., N.P. Arnold, F. Svejda, H. Marshall, L. Collicutt, and C. Davidson. 1993b. Winterhardy roses from Agriculture Canada. Agriculture Canada Publ. A53-1891/1993E.

Svejda, F. 1969. Hybrid rugosa rose 'Martin Frobisher'. Can. J. Plant Sci. 49:100.

Svejda, F. 1975. Hybrid rugosa rose cv. Jens Munk. Can. J. Plant Sci. 55:335-336.

Svejda, F. 1977. Hybrid rugosa rose cv. Henry Hudson. Can. J. Plant Sci. 57:303-304.

Svejda, F. 1978a. John Cabot rose. Can. J. Plant Sci. 58:907-908.

Svejda, F. 1978b. Breeding new Rosa rugosa hybrids. Can. Rose Annu. p. 29-33.

Svejda, F. 1979. David Thompson rose. Can. J. Plant Sci. 59:1167-1168.

Svejda, F. 1980. John Franklin rose. Can. J. Plant Sci. 60: 1053-1054.
Svejda, F. 1981 New winterhardy roses for Canadian gardens. Can. Rose Annu. p. 24-27.

Svejda, F. 1982. 'Charles Albanel' and 'Champlain' roses. HortScience 17:835-836.

Svejda,F. 1983. 'William Baffin' rose. HortScience $18: 962$.

Svejda. F. 1985. 'Henry Kelsey' rose. HortScience 20:454-455.

Svejda, F. 1986. 'A. Mackenzie' rose. HortScience 21:167-168.

Svejda, F. 1988. 'John Davis' and 'J.P. Connell' roses. HortScience 23:763-764.

Ian S. Ogilvie and Neville P. Arnold Agriculture Canada Research Branch

Experimental Farm P.O. Box 3398 801 Route 344

L'Assomption, Que. J0K 1G0, Canada 